\title{
Impact of Training Programme on Knowledge and Perception of Primary Health Care (PHC) Workers on Nutrition Component of Safe Motherhood Initiative in South-West Nigeria
}

\author{
Oyewole $\mathrm{OE}^{*}$ and Ahmadu $\mathrm{AA}^{2}$ \\ ${ }^{1}$ Department of Health Promotion and Education, College of Medicine, University of Ibadan, Nigeria \\ ${ }^{2}$ Department of Human Nutrition, College of Medicine, University of Ibadan, Nigeria
}

*Corresponding author: Oyewole OE, Department of Health Promotion and Education, College of Medicine, University of Ibadan, Nigeria, E-mail: oyewole2002@yahoo.com

Citation: Oyewole OE, Ahmadu AA (2014) Impact of Training Programme on Knowledge and Perception of Primary Health Care (Phc) Workers on Nutrition Component of Safe Motherhood Initiative in SouthWest Nigeria. J Nutr Health Sci 1(3): 304. doi: 10.15744/2393-9060.1.304

Received Date: April 08, 2014 Accepted Date: November 03, 2014 Published Date: November 06, 2014

\begin{abstract}
One of the core components of Safe Motherhood Initiatives (SMI) is nutrition, yet only few studies have considered this adequately. The goal of this intervention study was to evaluate the effect of training programme on knowledge and perception of PHC health workers on nutrition components of SMIs. The study was quasi-experimental involving two groups of 30 PHC health workers each purposively selected from Egbeda Local Government Area (LGA) (experimental group-EG) and Ido LGA (control group-CG). The two groups completed validated questionnaire at baseline. Knowledge and perception of nutrition components of SMIs were assessed using 42-point and 28-point scales respectively. Knowledge and perception gaps identified during the baseline survey were used to design module for training programme for the EG. Post-intervention assessment was conducted immediately and one month after the training among the two groups. These showed that knowledge scores at baseline, immediate post-intervention and one month postintervention were $12.6 \pm 2.9,36.9 \pm 3.6$ and $39.9 \pm 1.7$ respectively $(\mathrm{p}<0.05)$ and $12.2 \pm 2.8,13.7 \pm 2.8$ and $13.6 \pm 2.5$ respectively in the CG $(\mathrm{p}>0.05)$. Difference in knowledge scores between the EG and CG groups at the different stages of assessment was significant $(p<0.05)$, except at baseline. Perception scores at baseline, intervention and one month post-intervention for EG were 20.2 $\pm 4.8,21.1 \pm 2.3$ and 23.0 \pm 3.4 respectively compared with $19.2 \pm 3.8,20.3 \pm 3.6$ and $22.4 \pm 4.3$ in CG respectively ( $>>0.05)$. Training improved knowledge of health workers' but had insignificant effect on perception of nutrition components of SMIs. The PHC health workers have right perception of nutrition components of SMIs but lack adequate knowledge. There is need for continuous training of health workers' on nutrition components of SMI to enhance maternal and child care, especially at the PHC level.
\end{abstract}

Keywords: Safe Motherhood Initiative; Nutrition component; Training; Primary Health Workers

\section{Introduction}

The global campaign to reduce maternal mortality was launched in 1987, when three United Nations agencies - United Nations Population Fund (UNFPA), the World Bank, and World Health Organization (WHO) — sponsored the international Safe Motherhood Conference in Nairobi, Kenya. The event aimed to raise awareness about the numbers of women dying each year from complications of pregnancy and childbirth, and to challenge the world to intervene [1]. At that time the number of maternal deaths worldwide was estimated to be at least 600,000 each year - with $99 \%$ of deaths occurring in the developing world. In spite of the promises and good expectations associated with SMI when founded, the programme is yet to witness a quantum leap in progress to reduce maternal challenges. This may be related to neglect of some vital components in the planning of which nutrition is fundamental [15]. In Nigeria, maternal mortality ratio is put at 545 maternal deaths per 100,000 live births [2]. Safe Motherhood refers to a situation in which no woman going through the physiological processes of pregnancy and childbirth suffers any injury or loses her life or that of the baby [3].

Most maternal deaths occur in the developing world; making maternal mortality the health statistics with the largest disparity between developed and developing countries [4]. The consequences of malnutrition, in all its forms (both macronutrients and micronutrients) can be seen in poor birth outcomes and poor breast-feeding and other infant feeding and care practices.

Rapid and progressive physiological changes that occur during pregnancy require supply of adequate nutrients, especially some micronutrients that are needed during the first trimester to help in ensuring in cell division and multiplication. Women in developing countries may benefit from multiple-micronutrient prophylaxis in pregnancy, but the underlying basis and rationale for changing from supplementation with iron and folate to supplementation with multiple micronutrients has not been debated in the context of existing programme objectives [16]. In Nigeria, iodine deficiency among pregnant women causes $3 \%$ of children born to suffer cretinism, $10 \%$ moderate to severe mental retardation, $87 \%$ mild intellectual impairment and $20 \%$ goitre while vitamin A deficiency accounts for 300,000 child deaths [5,6]. 
The components of SMI include pre-conception care, which consists of information and services given to an individual or couple who intend to biologically raise a child. It also includes ante-natal care and education given to a woman during pregnancy. The purpose is to help achieve optimal maternal and infant outcome as much as possible. In addition, SMI considers post-partum care, which encompasses management of the mother, newborn, and infant during the first few days after delivery up to the mother's post-partum check-up with her health care provider. Immediate breastfeeding after birth has been found to help mothers by stimulating the contractions of the uterus that protects against severe bleeding and it equally protects infants by providing nutrients and essential immunities from disease [17].

Nutrition component of safe motherhood concept is considered from four perspectives, which include food intake, basic hygiene and sanitation, health status and access to evidence-based nutrition information. For the purpose of this study, more emphasis is laid on food intake as one of the key components of SMI. Optimal nutritional status prior to pregnancy enhances the likelihood of conception and helps ensure a healthy pregnancy outcome. Access to and consumption of iodized salt in order to control iodine deficiency disorders is of utmost important to SMI [7]. Maintenance of a healthy body weight, using Body Mass Index (BMI) between of 18.5-24.9 as cut-off point before pregnancy is required for every woman of reproductive age. Reduce workload and rest to conserve energy and prevention of diseases and infection such as diabetes, hypertension that may be transmitted to offspring are all the essential nutrition component of SMI [7].

Rather than focusing exclusively on the prenatal period, it is important to describe a life cycle approach to improving maternal nutrition, which goes beyond the traditional provision of nutrition services during pregnancy, by addressing risk factors that are present well before pregnancy, even before childbearing age, which include nutrition of girl and adolescent child [18]. Potential risks of childbearing can be greatly reduced if a woman is healthy and well-nourished before becoming pregnant, if she has a health check-up by a trained health worker at least four times during every pregnancy, and if the birth is assisted by a skilled birth attendant such as a doctor, nurse or midwife [8]. In Nigeria, more than half of women who had a live birth received antenatal care from a health professional (58\%); $23 \%$ from a doctor, 30\% from a nurse or midwife and 5\% from an auxiliary nurse or midwife. Thirty-six percent of mothers did not receive any antenatal care [2].

Adequate and relevant knowledge of nutrition is required to prevent complication during delivery. Unguided supplementary feeding could increase risk of obstructed labour, especially among primiparous women $<1.5 \mathrm{~m}$ in height and should be avoided when there is poor access to obstetric care [19]. Training of health professionals has been found to improve significantly the course of safe motherhood initiative. Therefore, exposing them to basic training in nutrition components of SMI will go a long way in ensuring the success of the initiative [20]. Presently, there is dearth of information on knowledge of nutrition component of SMI among health workers at the PHC level in Nigeria. The objective of this study was to investigate the impact of training on knowledge gaps of health workers on nutrition component of SMI.

\section{Material and Methods}

\section{Study design and Location}

This was an intervention study, with a quasi- experimental design. Two groups of professionally similar primary health care workers were identified and purposively selected from two different communities, namely: Egbeda and Ido. Egbeda and Ido LGAs share similar characteristics, consisting of both urban and rural communities. These were designated as the Experimental Group (EG) and Control Group (CG), respectively. Both the EG and CG consisted of 30 consented primary health care workers each from Egbeda and Ido PHCs in Oyo State of Nigeria. An interviewer-administered semi-structured questionnaire was used to collect baseline information, which included 42-point and 28-point scales to assess knowledge and perception. The scales were developed from nutrition variables under the Essential Nutrition Actions by USAID [21]. Knowledge score was categorized as poor (0-20) and good $(>20)$ while the perception score was classified as wrong (0-13) and right (>13). The Principal Investigator and Coinvestigator were involved in the administration of the questionnaire. The instrument was developed by both investigators and was equally pre-tested together. Interviewer's variability in questionnaire administration was not observed as the two interviewers worked together. A training guide was developed based on the gaps identified from the survey conducted on the two groups, using the Academy for Educational Development standard [9]. The experimental group received a two-day training, using the training guide as intervention tool while the control group received placebo training on HIV/AIDS prevention, which was not directly related to the focus of intervention. Once a week, a reminder text message was sent to the experimental group for a month post-training to serve as reinforcement to the training programme. However, at the end of the study, the control groups were also trained based on principle of ethics. At the end of the two trainings, both groups were subjected to immediate and one-month post-training evaluation.

\section{Validity and reliability of instrument}

Review of relevant literature, comments from experts in public health disciplines were conducted for face and content validity. The questionnaire was pre-tested for reliability and the Cronbach Alpha value was 0.76 after adjustments were made on the initial draft. 


\section{Data Management and Analysis}

The questionnaire was sorted, cleaned and coded, using coding guide. Data were subsequently entered into the computer, using SPSS Version 15.0 for analysis. Data were analyzed using descriptive statistics (mean, percentage, frequency etc) and t-test was run using Wilcoxon's test because the sampling was non- parametric.

\section{Ethical Consideration}

The study followed the ethical principles guiding the use of human participants in research. Ethical approval was sought from the ethics review committee of University College Hospital, Ibadan, Nigeria.

\section{Results}

\section{Socio-demographic characteristics for the experimental and control groups}

Socio-demographic characteristics of the participants are presented in Table 1. Age of the experimental and control groups were $46.0 \pm 4.0$ and $47.6 \pm 5.5$ years respectively. More of the participants (86.7\%) were within the $41-60$ years age bracket among the experimental group and $80.0 \%$ were within the same age bracket among control group. All the participants were female in both groups. All the respondents in both groups were Yoruba and claimed to have tertiary level of education. A majority of the respondents $(80.0 \%)$ were Community Health Worker, $20.0 \%$ were Nurse among the experimental group while $93.3 \%$ were Community Health Worker and 6.7\% were Nurse among the control group. Majority (93.3\%) of experimental and control (96.7\%) groups had been providing health care services for $\leq 20$ years.

\begin{tabular}{|c|c|c|c|c|c|}
\hline \multirow[t]{2}{*}{ Characteristic } & \multirow[t]{2}{*}{ Category } & \multicolumn{2}{|c|}{ Experimental $(\mathrm{N}=30)$} & \multicolumn{2}{|c|}{ Control(N=30) } \\
\hline & & $\mathrm{N}$ & $\%$ & $\mathrm{~N}$ & $\%$ \\
\hline \multicolumn{6}{|c|}{ Age group (yrs) } \\
\hline $20-40$ & & 4 & 13.3 & 6 & 20.0 \\
\hline $41-60$ & & 26 & 86.7 & 24 & 80.0 \\
\hline Sex & Female & 30 & 100.0 & 30 & 100.0 \\
\hline Ethnicgroup & Yoruba & 30 & 100.0 & 30 & 100.0 \\
\hline Educational status & Tertiary & 30 & 100.0 & 30 & 100.0 \\
\hline \multirow{2}{*}{ Current qualification } & Nurse & 6 & 20.0 & 2 & 6.7 \\
\hline & Community Health Worker & 24 & 80.0 & 28 & 93.3 \\
\hline \multirow{2}{*}{ Years of Service } & $0-20$ & 28 & 93.3 & 29 & 96.7 \\
\hline & $21-40$ & 2 & 6.7 & 1 & 3.3 \\
\hline
\end{tabular}

Table 1: Socio-demographic characteristics of experimental and control groups at pre-intervention.

\section{Knowledge of Nutrition Component of Safe Motherhood Initiatives at Pre-test among the Experimental and Control Groups}

Table 2 shows participants' knowledge of nutrition component of SMI at pre-test. None from both the experimental and control groups had good knowledge of SMI. However, 28 (93.3\%) participants in the experimental and 25 (83.3\%) in the control group had poor knowledge of what SMI entails while 2 (6.7\%) in the experimental group and $5(16.7 \%)$ in the control group had no knowledge of such. No member of both groups had good knowledge of two components of SMI but 19 (63.3\%) participants in the experimental group compared to 15 (50.0\%) in the control group had poor knowledge of component of SMI. Similarly, in all the other variables listed in the table, no members of the two groups had good knowledge of all nutrition-related component of SMI at pre-test. However, data presented show that some of them (both in the experimental and control groups) had poor knowledge of some of the listed variables.

Knowledge of the Nutrition Component of Safe Motherhood Initiative at Post-test among the Experimental and Control Groups

Table 3 shows participants' knowledge of nutrition component of SMI at post-test. Sixteen (53.3\%) participants in the experimental group and none in the control group had good knowledge of what SMI is all about. However, 14 (46.7\%) participants in the experimental and $27(90.0 \%)$ in the control groups still had poor knowledge of the same subject matter while none of the participants in the experimental group and $3(10.0 \%)$ in the control group had no knowledge of such after the training. Similar trends were observed in all the other variables tested as the data are presented in Table 3. 


\begin{tabular}{|c|c|c|c|c|c|}
\hline \multirow{2}{*}{ Variables } & \multirow{2}{*}{$\begin{array}{l}\text { Response basedon the Content of } \\
\text { the TrainingModule }\end{array}$} & \multicolumn{2}{|c|}{ Experimental } & \multicolumn{2}{|c|}{ Control } \\
\hline & & $\mathbf{N}$ & $\%$ & $\mathbf{N}$ & $\%$ \\
\hline \multirow{3}{*}{$\begin{array}{l}\text { Understanding of safe } \\
\text { motherhood }\end{array}$} & Good & 0 & 0.0 & 0 & 0.0 \\
\hline & Poor & 28 & 93.3 & 25 & 83.3 \\
\hline & Nil & 2 & 6.7 & 5 & 16.7 \\
\hline \multirow{3}{*}{$\begin{array}{l}\text { List } 2 \text { components of safe } \\
\text { motherhood initiative }\end{array}$} & Good & 0 & 0.0 & 0 & 0.0 \\
\hline & Poor & 19 & 63.3 & 15 & 50.0 \\
\hline & Nil & 11 & 36.7 & 15 & 50.0 \\
\hline \multirow{3}{*}{$\begin{array}{l}\text { State } 2 \text { nutrition related } \\
\text { information that should be } \\
\text { given to women of repro- } \\
\text { ductive age at preconception } \\
\text { care }\end{array}$} & Good & 0 & 0.0 & 0 & 0.0 \\
\hline & Poor & 20 & 66.7 & 16 & 53.3 \\
\hline & Nil & 10 & 33.3 & 14 & 46.7 \\
\hline \multirow{3}{*}{$\begin{array}{c}\text { Mention } 3 \text { food sources of } \\
\text { Vitamin A }\end{array}$} & Good & 0 & 0.0 & 0 & 0.0 \\
\hline & Poor & 23 & 76.7 & 17 & 56.7 \\
\hline & Nil & 7 & 23.3 & 13 & 43.3 \\
\hline \multirow{3}{*}{$\begin{array}{l}\text { List } 2 \text { specific nutrients (mi- } \\
\text { cronutrients) required at the } \\
\text { first trimester of pregnancy }\end{array}$} & Good & 0 & 0.0 & 0 & 0.0 \\
\hline & Poor & 15 & 50.0 & 11 & 36.7 \\
\hline & Nil & 15 & 50.0 & 19 & 63.3 \\
\hline \multirow{3}{*}{$\begin{array}{l}\text { Mention } 3 \text { food sources } \\
\text { of these specific nutrients } \\
\text { listed in question } 5 \text { above }\end{array}$} & Good & 0 & 0.0 & 0 & 0.0 \\
\hline & Poor & 24 & 80.0 & 20 & 66.7 \\
\hline & Nil & 6 & 20.0 & 10 & 33.3 \\
\hline \multirow{3}{*}{$\begin{array}{l}\text { Mention } 2 \text { groups of people } \\
\text { that are vulnerable to } \\
\text { under-nutrition }\end{array}$} & Good & 0 & 0.0 & 0 & 0.0 \\
\hline & Poor & 19 & 63.3 & 16 & 53.3 \\
\hline & Nil & 11 & 36.7 & 14 & 46.7 \\
\hline \multirow{3}{*}{$\begin{array}{l}\text { State } 2 \text { benefits of family } \\
\text { planning services in relation } \\
\text { to safe motherhood concept }\end{array}$} & Good & 0 & 0.0 & 0 & 0.0 \\
\hline & Poor & 11 & 36.7 & 12 & 40.0 \\
\hline & Nil & 19 & 63.3 & 18 & 60.0 \\
\hline \multirow{3}{*}{$\begin{array}{l}\text { Mention } 2 \text { ways that women } \\
\text { of child-bearing age can be } \\
\text { economically empowered }\end{array}$} & Good & 0 & 0.0 & 0 & 0.0 \\
\hline & Poor & 13 & 43.3 & 11 & 36.7 \\
\hline & Nil & 17 & 56.7 & 19 & 63.3 \\
\hline \multirow{3}{*}{$\begin{array}{l}\text { Mention } 2 \text { ways of helping } \\
\text { pregnant and lactating } \\
\text { women reduced their } \\
\text { workload to reduce calorie } \\
\text { (nutrient) depletion }\end{array}$} & Good & 0 & 0.0 & 0 & 0.0 \\
\hline & Poor & 14 & 46.7 & 10 & 33.3 \\
\hline & Nil & 16 & 53.3 & 20 & 66.7 \\
\hline
\end{tabular}

Good: the participant was able to give correct response to the question as stated in the training module/guide Poor: the participant responded faintly to the question as stated in the training module/guide Nil: the participant could not respond at all to the question asked

Table 2: Knowledge of Nutrition Component of SMI among Experimental and Control groups at Pre-Test $(\mathrm{N}=30)$

\begin{tabular}{|c|c|c|c|c|c|}
\hline \multirow{2}{*}{ Variables } & \multirow{2}{*}{$\begin{array}{l}\text { Response based } \\
\text { on the Content of } \\
\text { the Training } \\
\text { Module }\end{array}$} & \multicolumn{2}{|c|}{ Experimental } & \multicolumn{2}{|c|}{ Control } \\
\hline & & $\mathbf{N}$ & $\%$ & $\mathbf{N}$ & $\%$ \\
\hline \multirow{3}{*}{$\begin{array}{l}\text { Understanding of safe } \\
\text { motherhood }\end{array}$} & Good & 16 & 53.3 & 0 & 0.0 \\
\hline & Poor & 14 & 46.7 & 27 & 90.0 \\
\hline & Nil & 0 & 0.0 & 3 & 10.0 \\
\hline
\end{tabular}




\begin{tabular}{|c|c|c|c|c|c|}
\hline \multirow{2}{*}{ Variables } & \multirow{2}{*}{$\begin{array}{l}\text { Response based } \\
\text { on the Content of } \\
\text { the Training } \\
\text { Module }\end{array}$} & \multicolumn{2}{|c|}{ Experimental } & \multicolumn{2}{|c|}{ Control } \\
\hline & & $\mathbf{N}$ & $\%$ & $\mathbf{N}$ & $\%$ \\
\hline \multirow{3}{*}{$\begin{array}{l}\text { List } 2 \text { components of safe } \\
\text { motherhood initiative }\end{array}$} & Good & 27 & 90.0 & 0 & 0.0 \\
\hline & Poor & 3 & 10.0 & 17 & 56.7 \\
\hline & Nil & 0 & 0.0 & 13 & 43.3 \\
\hline \multirow{3}{*}{$\begin{array}{l}\text { State } 2 \text { nutrition related } \\
\text { information that should be } \\
\text { given to women of repro- } \\
\text { ductive age at preconception } \\
\text { care }\end{array}$} & Good & 16 & 53.3 & 0 & 0.0 \\
\hline & Poor & 14 & 46.7 & 19 & 63.3 \\
\hline & Nil & 0 & 0.0 & 11 & 36.7 \\
\hline \multirow{3}{*}{$\begin{array}{c}\text { Mention } 3 \text { food sources of } \\
\text { Vitamin A }\end{array}$} & Good & 24 & 80.0 & 0 & 0.0 \\
\hline & Poor & 6 & 20.0 & 19 & 63.3 \\
\hline & Nil & 0 & 0.0 & 11 & 36.7 \\
\hline \multirow{3}{*}{$\begin{array}{l}\text { List } 2 \text { specific nutrients (mi- } \\
\text { cronutrients) required at the } \\
\text { first trimester of pregnancy }\end{array}$} & Good & 27 & 90.0 & 0 & 0.0 \\
\hline & Poor & 3 & 10.0 & 16 & 53.3 \\
\hline & Nil & 0 & 0.0 & 14 & 46.7 \\
\hline \multirow{3}{*}{$\begin{array}{l}\text { Mention } 3 \text { food sources } \\
\text { of these specific nutrients } \\
\text { listed in question } 5 \text { above }\end{array}$} & Good & 25 & 83.3 & 0 & 0.0 \\
\hline & Poor & 5 & 16.7 & 22 & 73.3 \\
\hline & Nil & 0 & 0.0 & 8 & 26.7 \\
\hline \multirow{3}{*}{$\begin{array}{l}\text { Mention } 2 \text { groups of people } \\
\text { that are vulnerable to } \\
\text { under-nutrition }\end{array}$} & Good & 26 & 86.7 & 0 & 0.0 \\
\hline & Poor & 4 & 13.3 & 19 & 63.3 \\
\hline & Nil & 0 & 0.0 & 11 & 36.7 \\
\hline \multirow{3}{*}{$\begin{array}{l}\text { State } 2 \text { benefits of family } \\
\text { planning services in relation } \\
\text { to safe motherhood concept }\end{array}$} & Good & 21 & 70.0 & 0 & 0.0 \\
\hline & Poor & 9 & 30.0 & 13 & 43.3 \\
\hline & Nil & 0 & 0.0 & 17 & 56.7 \\
\hline \multirow{3}{*}{$\begin{array}{l}\text { Mention } 2 \text { ways that women } \\
\text { of child-bearing age can be } \\
\text { economically empowered }\end{array}$} & Good & 16 & 53.3 & 0 & 0.0 \\
\hline & Poor & 14 & 46.7 & 15 & 50.0 \\
\hline & Nil & 0 & 0.0 & 15 & 50.0 \\
\hline \multirow{3}{*}{$\begin{array}{l}\text { Mention } 2 \text { ways of helping } \\
\text { pregnant and lactating } \\
\text { women reduced their } \\
\text { workload to reduce calorie } \\
\text { (nutrient) depletion }\end{array}$} & Good & 23 & 76.7 & 0 & 0.0 \\
\hline & Poor & 7 & 23.3 & 13 & 43.3 \\
\hline & Nil & 0 & 0.0 & 17 & 56.7 \\
\hline
\end{tabular}

Table 3: Knowledge of Nutrition Component of SMI among Experimental and Control groups at Post-Test $(\mathrm{N}=30)$

\section{Knowledge of the Nutrition Component of Safe Motherhood Initiative at One Month Follow up (Post-test) among Experimental and Control Groups}

Table 4 shows participants' knowledge of nutrition components of safe motherhood initiatives at one month follow up (post-test). Twenty-three participants $(82.1 \%)$ in the experimental group and none in the control group had good understanding of safe motherhood; five participants (17.9\%) in the experimental group and 25 (83.3\%) in the control group had poor understanding of safe motherhood. Twenty-seven participants (96.4\%) in the experimental group and none in the control group could mention two nutrition components of SMI. Twenty-two participants (78.6\%) in the experimental group and none in the control group were able to mention two nutrition-related information that should be given to women of reproductive age at pre-conception care. Six participants $(21.4 \%)$ in the experimental group compared to $18(60.0 \%)$ in the control group had poor knowledge. Twenty-seven participants (96.4\%) in the experimental group and none in the control group were able to mention three food sources of vitamin A; only one participant (3.6\%) in the experimental group compared to 19 (63.3\%) in the control group were able to mention only one food source of vitamin A. Twenty-five participants (89.3\%) in the experimental group and none in the control group were able to list two specific micronutrients required during the first trimester of pregnancy; three participants (10.7\%) in the experimental group compared to $17(56.7 \%)$ in the control group could mention only one specific micronutrient required during the same period. Twenty- six participants (92.9\%)in the experimental group and none in the control group were able to mention three food 
sources of the specific micronutrients required during first trimester of pregnancy; only two participants (7.1\%) in the experimental group compared to $21(70.0 \%)$ in the control group were able to mention one of such food sources. Twenty-six participants $(92.9 \%)$ in the experimental group and none in the control group were able to mention two groups of people who are vulnerable to under-nutrition; two participants $(7.1 \%)$ in the experimental group compared to $18(60.0 \%)$ in the control group were able to mention only one vulnerable group of people. Twenty-three participants $(82.1 \%)$ in the experimental group and none in the control group were able to state two benefits of family planning services in relation to SMI; five participants (17.9\%) in the experimental group compared to $13(43.3 \%)$ in the control group were able to state one of the benefits. Twenty-four participants $(85.7 \%)$ in the experimental group and none in the control group were able to mention two ways women of child-bearing age can be economically empowered; four (14.3\%) participants in the experimental group compared to 16 (53.3\%) in the control group were able to mention only one of the ways. Twenty-six participants (92.9\%) in the experimental group and none in the control group were able to mention two ways of helping pregnant and lactating women reduced their workload to conserve energy and prevent depletion; two participants $(7.1 \%)$ in the experimental group compared to $12(40.0 \%)$ in the control group were able to mention only one way.

\begin{tabular}{|c|c|c|c|c|c|}
\hline \multirow{2}{*}{ Variables } & \multirow{2}{*}{$\begin{array}{l}\text { Response basedon the Content of } \\
\text { the TrainingModule }\end{array}$} & \multicolumn{2}{|c|}{ Experimental } & \multicolumn{2}{|c|}{ Control } \\
\hline & & $\mathrm{N}$ & $\%$ & $\mathbf{N}$ & $\%$ \\
\hline \multirow{3}{*}{$\begin{array}{l}\text { Understanding of safe } \\
\text { motherhood }\end{array}$} & Good & 23 & 82.1 & 0 & 0.0 \\
\hline & Poor & 5 & 17.9 & 25 & 83.3 \\
\hline & Nil & 0 & 0.0 & 5 & 16.7 \\
\hline \multirow{3}{*}{$\begin{array}{l}\text { List } 2 \text { components of safe } \\
\text { motherhood initiative }\end{array}$} & Good & & 96.4 & 0 & 0.0 \\
\hline & Poor & 1 & 3.6 & 15 & 50.0 \\
\hline & Nil & 0 & 0.0 & 15 & 50.0 \\
\hline \multirow{3}{*}{$\begin{array}{l}\text { State } 2 \text { nutrition related } \\
\text { information that should be } \\
\text { given to women of repro- } \\
\text { ductive age at preconception } \\
\text { care }\end{array}$} & Good & & 78.6 & 0 & 0.0 \\
\hline & Poor & 6 & 21.4 & 18 & 60.0 \\
\hline & Nil & 0 & 0.0 & 12 & 40.0 \\
\hline \multirow{3}{*}{$\begin{array}{c}\text { Mention } 3 \text { food sources of } \\
\text { Vitamin A }\end{array}$} & Good & 27 & 96.4 & 0 & 0.0 \\
\hline & Poor & 1 & 3.6 & 19 & 63.3 \\
\hline & Nil & 0 & 0.0 & 11 & 36.7 \\
\hline \multirow{3}{*}{$\begin{array}{l}\text { List } 2 \text { specific nutrients (mi- } \\
\text { cronutrients) required at the } \\
\text { first trimester of pregnancy }\end{array}$} & Good & 25 & 89.3 & 0 & 0.0 \\
\hline & Poor & 2 & 10.7 & 17 & 56.7 \\
\hline & Nil & 0 & 0.0 & 13 & 43.3 \\
\hline \multirow{3}{*}{$\begin{array}{l}\text { Mention } 3 \text { food sources } \\
\text { of these specific nutrients } \\
\text { listed in question } 5 \text { above }\end{array}$} & Good & 26 & 86.7 & 0 & 0.0 \\
\hline & Poor & 2 & 6.7 & 21 & 70.0 \\
\hline & Nil & 2 & 6.6 & 9 & 30.0 \\
\hline \multirow{3}{*}{$\begin{array}{l}\text { Mention } 2 \text { groups of people } \\
\text { that are vulnerable to } \\
\text { under-nutrition }\end{array}$} & Good & & 86.7 & 0 & 0.0 \\
\hline & Poor & 2 & 6.7 & 18 & 60.0 \\
\hline & Nil & 2 & 6.6 & 12 & 40.0 \\
\hline \multirow{3}{*}{$\begin{array}{l}\text { State } 2 \text { benefits of family } \\
\text { planning services in relation } \\
\text { to safe motherhood concept }\end{array}$} & Good & & 76.7 & 0 & 0 \\
\hline & Poor & 4 & 13.3 & 13 & 43.3 \\
\hline & Nil & 3 & 1.0 & 17 & 56.7 \\
\hline \multirow{3}{*}{$\begin{array}{l}\text { Mention } 2 \text { ways that women } \\
\text { of child-bearing age can be } \\
\text { economically empowered }\end{array}$} & Good & & 80.0 & 0 & 0.0 \\
\hline & Poor & 2 & 6.7 & 16 & 53.3 \\
\hline & Nil & 4 & 13.3 & 14 & 46.7 \\
\hline \multirow{3}{*}{$\begin{array}{l}\text { Mention } 2 \text { ways of helping } \\
\text { pregnant and lactating } \\
\text { women reduced their } \\
\text { workload to reduce calorie } \\
\text { (nutrient) depletion }\end{array}$} & Good & & 86.7 & 0 & 0.0 \\
\hline & Poor & 2 & 6.7 & 12 & 40.0 \\
\hline & Nil & 2 & 6.6 & 18 & 60.0 \\
\hline
\end{tabular}

Table 4: Knowledge of Nutrition Component of SMI among Experimental and Control groups One Month Follow up (Post-test) $\mathrm{N}=30$ 
Overall, knowledge scores at baseline, immediate post-intervention and one month post-intervention were 12.6 $\pm 2.9,36.9 \pm 3.6$ and $39.9 \pm 1.7$ respectively in the experimental group $(\mathrm{p}<0.05)$ and $12.2 \pm 2.8,13.7 \pm 2.8$ and $13.6 \pm 2.5$ respectively in the control group $(p>0.05)$. Difference in knowledge scores between the experimental and control groups at the different stages of assessment was significant $(\mathrm{p}<0.05)$, except at baseline.

\section{Current Qualifications and Knowledge of Experimental and Control groups on the Nutrition Component of Safe Motherhood Initiative}

Table 5 shows the current qualification and knowledge of experimental and control groups on nutrition components of SMI. At pre-test, six (100.0\%) of the Nurses in the experimental group and two (100.0\%) of the Nurses in the control group had no knowledge of nutrition component of SMI while among the Community Health Workers, 24 (100.0\%) in the experimental group and $28(100.0 \%)$ in the control group had no knowledge of the nutrition component of safe motherhood initiatives with no significant difference $(\mathrm{p}>0.05)$.

At post-test, six (100.0\%) of the Nurses in the experimental group and none in the control group had good knowledge of nutrition component of SMI while among the Community Health Workers, 24 (100.0\%) in the experimental group and none in the control group had good knowledge of nutrition component of safe motherhood initiatives with significant difference $(\mathrm{p}<0.05)$. Cadre of health workers did not significantly associate with knowledge of nutrition component of SMI.

At one month follow up (post-test), six (100.0\%) of the Nurses in the experimental group and none in the control group had good knowledge of nutrition component of SMI while among the Community Health Workers, 22 (100.0\%) in the experimental group and none in the control group had good knowledge of nutrition components of SMI.

\begin{tabular}{|c|c|c|c|c|c|c|c|c|c|c|c|}
\hline \multirow{4}{*}{ Variables } & \multirow{4}{*}{ Stage } & \multirow{4}{*}{ Category } & \multirow{2}{*}{\multicolumn{4}{|c|}{$\begin{array}{c}\text { Experimental } \\
\text { Knowledge } \\
\end{array}$}} & \multirow{2}{*}{\multicolumn{4}{|c|}{$\begin{array}{c}\text { Control } \\
\text { Knowledge }\end{array}$}} & \multirow{4}{*}{ P-value } \\
\hline & & & & & & & & & & & \\
\hline & & & \multicolumn{2}{|c|}{ Good } & \multicolumn{2}{|c|}{ Poor } & \multicolumn{2}{|c|}{ Good } & \multicolumn{2}{|c|}{ Poor } & \\
\hline & & & $\mathbf{N}$ & $\%$ & $\mathbf{N}$ & $\%$ & $\mathbf{N}$ & $\%$ & $\mathbf{N}$ & $\%$ & \\
\hline \multirow{4}{*}{$\begin{array}{l}\text { Current } \\
\text { qualification }\end{array}$} & \multirow[b]{2}{*}{ Pre-test } & Nurse & 0 & 0.0 & 6 & 100.0 & 0 & 0.0 & 2 & 100.0 & \multirow[b]{2}{*}{$>0.05$} \\
\hline & & $\begin{array}{l}\text { Community } \\
\text { Health Worker }\end{array}$ & 0 & 0.0 & 24 & 100.0 & 0 & 0.0 & 28 & 100.0 & \\
\hline & \multirow{2}{*}{ Post-test } & Nurse & 6 & 100.0 & 0 & 0.0 & 0 & 0.0 & 2 & 100.0 & \multirow[b]{2}{*}{$<0.05$} \\
\hline & & $\begin{array}{l}\text { Community } \\
\text { Health Worker }\end{array}$ & 24 & 100.0 & 0 & 0.0 & 0 & 0.0 & 28 & 100.0 & \\
\hline & \multirow{2}{*}{$\begin{array}{c}\text { One } \\
\text { Month Follow } \\
\text { up (Post- test) }\end{array}$} & Nurse & 6 & 100.0 & 0 & 0.0 & 0 & 0.0 & 2 & 100.0 & \multirow[b]{2}{*}{$<0.05$} \\
\hline & & $\begin{array}{l}\text { Community } \\
\text { Health Worker }\end{array}$ & 22 & 100.0 & 0 & 0.0 & 0 & 0.0 & 28 & 100.0 & \\
\hline
\end{tabular}

Table 5: Current Qualification and Knowledge of Experimental and Control groups on the Nutrition Component of Safe Motherhood Initiative $(\mathrm{N}=30)$

\section{Years of Service and Knowledge of Experimental and Control groups on Nutrition Component of SMI}

Table 6 shows years of service and knowledge of experimental and control groups on the nutrition component of SMI. At pre-test, $28(100.0 \%)$ of the participants who had worked for $0-20$ years in the experimental group and 29 (100.0\%) in the control group had no knowledge of nutrition component of SMI. Among those who had worked for 21-40 years, two (100.0\%) of the participants in the experimental group and only one (100.0\%) in the control group had no knowledge of nutrition component of SMI ( $\mathrm{p}>0.05$ ).

At post-test, 28 (100.0\%) of the participants who had worked for 0-20 years in the experimental group and none in the control group had good knowledge of the nutrition components of SMI. However, among those who had worked for 21-40 years, two participants (100.0\%) in the experimental group and none in the control group had good knowledge of nutrition component of SMI.

Data in Table 6 show that at one month follow up (post-test), 26 (100.0\%) of the participants who had worked for 0-20 years in the experimental group and none in the control group had good knowledge of nutrition components of SMI. In addition, among those who had worked for 21-40 years, two participants (100.0\%) in the experimental group and none in the control group had good knowledge of the same subject matter. 


\begin{tabular}{|c|c|c|c|c|c|c|c|c|c|c|}
\hline \multirow{4}{*}{ Stage } & \multirow{4}{*}{$\begin{array}{l}\text { Years of } \\
\text { Service }\end{array}$} & \multicolumn{4}{|c|}{ Experimental } & \multicolumn{4}{|c|}{ Control } & \multirow{4}{*}{ P-value } \\
\hline & & \multicolumn{4}{|c|}{ Knowledge } & \multicolumn{4}{|c|}{ Knowledge } & \\
\hline & & \multicolumn{2}{|c|}{ Good } & \multicolumn{2}{|c|}{ Poor } & \multicolumn{2}{|c|}{ Good } & \multicolumn{2}{|c|}{ Poor } & \\
\hline & & $\mathbf{N}$ & $\%$ & $\mathbf{N}$ & $\%$ & $\mathbf{N}$ & $\%$ & $\mathbf{N}$ & $\%$ & \\
\hline \multirow{2}{*}{ Pre-test } & $00-20$ & 0 & 0.0 & 28 & 100.0 & 0 & 0.0 & 29 & 100.0 & \multirow{2}{*}{$>0.05$} \\
\hline & $21-40$ & 0 & 0.0 & 2 & 100.0 & 0 & 0.0 & 1 & 100.0 & \\
\hline \multirow{2}{*}{ Post-test } & $0-20$ & 28 & 100.0 & 0 & 0.0 & 0 & 0.0 & 29 & 100.0 & \multirow{2}{*}{$<0.05$} \\
\hline & $21-40$ & 2 & 100.0 & 0 & 0.0 & 0 & 0.0 & 1 & 100.0 & \\
\hline \multirow{2}{*}{$\begin{array}{c}\text { One } \\
\text { Month Follow up } \\
\text { (Post- test) }\end{array}$} & $0-20$ & 26 & 100. & 0 & 0.0 & 0 & 0.0 & 29 & 100.0 & \multirow[b]{2}{*}{$<0.05$} \\
\hline & $21-40$ & 2 & 100.0 & 0 & 0.0 & 0 & 0.0 & 1 & 100.0 & \\
\hline
\end{tabular}

Table 6: Years of Service and Knowledge of Experimental and Control groups on the Nutrition Components of Safe Motherhood Initiatives $(\mathrm{N}=30)$

\section{Cadres of Health Worker and Perception of Experimental and Control groups on the Nutrition Component of SMI}

Table 7 shows the cadres of health workers and perception of experimental and control groups on the nutrition components of safe motherhood initiatives. At pre-test, six (100.0\%) of the Nurses in the experimental group and two (100.0\%) of the Nurses in the control group had right perception of nutrition component of SMI while among the Community Health Workers, 24 (100.0\%) in the experimental group and $28(100.0 \%)$ in the control group had right perception of nutrition component of SMI. Similar results were obtained at post-test and one month follow-up post-test with no significant difference ( $\mathrm{p}>0.05)$. Generally, perception scores at baseline, intervention and one month post-intervention for experimental group were 20.2 $\pm 4.8,21.1 \pm 2.3$ and $23.0 \pm 3.4$ respectively compared with $19.2 \pm 3.8,20.3 \pm 3.6$ and $22.4 \pm 4.3$ in control respectively $(\mathrm{p}>0.05)$.

\begin{tabular}{|c|c|c|c|c|c|c|c|c|c|c|}
\hline \multirow{4}{*}{$\begin{array}{c}\text { Stage of } \\
\text { Intervention }\end{array}$} & \multirow{4}{*}{$\begin{array}{c}\text { Cadres of Health } \\
\text { Workers }\end{array}$} & \multirow{2}{*}{\multicolumn{4}{|c|}{$\begin{array}{c}\text { Experimental } \\
\text { Knowledge }\end{array}$}} & \multirow{2}{*}{\multicolumn{4}{|c|}{$\begin{array}{c}\text { Control } \\
\text { Knowledge }\end{array}$}} & \multirow{4}{*}{ P-value } \\
\hline & & & & & & & & & & \\
\hline & & \multicolumn{2}{|c|}{ Good } & \multicolumn{2}{|c|}{ Poor } & \multicolumn{2}{|c|}{ Good } & \multicolumn{2}{|c|}{ Poor } & \\
\hline & & $\mathbf{N}$ & $\%$ & $\mathbf{N}$ & $\%$ & $\mathbf{N}$ & $\%$ & $\mathbf{N}$ & $\%$ & \\
\hline \multirow[b]{2}{*}{ Pre-test } & Nurse & 6 & 100.0 & 0 & 0.0 & 2 & 100.0 & 0 & 0.0 & \multirow[b]{2}{*}{$>0.05$} \\
\hline & $\begin{array}{c}\text { Community Health } \\
\text { Worker }\end{array}$ & 24 & 100.0 & 0 & 0.0 & 28 & 100.0 & 0 & 0.0 & \\
\hline \multirow{2}{*}{ Post-test } & Nurse & 6 & 100.0 & 0 & 0.0 & 2 & 100.0 & 0 & 0.0 & \multirow[b]{2}{*}{$<0.05$} \\
\hline & $\begin{array}{c}\text { Community Health } \\
\text { Worker }\end{array}$ & 24 & 100.0 & 0 & 0.0 & 28 & 100.0 & 0 & 0.0 & \\
\hline \multirow{2}{*}{$\begin{array}{c}\text { One } \\
\text { Month Follow } \\
\text { up (Post- test) }\end{array}$} & Nurse & 6 & 100.0 & 0 & 0.0 & 2 & 100.0 & 0 & 0.0 & \multirow[b]{2}{*}{$<0.05$} \\
\hline & $\begin{array}{c}\text { Community Health } \\
\text { Worker }\end{array}$ & 22 & 100.0 & 0 & 0.0 & 28 & 100.0 & 0 & 0.0 & \\
\hline
\end{tabular}

Table 7: Cadres of Health Worker and Perception of Experimental and Control groups on the Nutrition Components of Safe Motherhood Initiatives $(\mathrm{N}=30)$

\section{Discussion}

Participants in the experimental and control groups in this study had no knowledge of the nutrition component of SMI at preintervention. This lack of knowledge may be a reflection of no understanding of health workers on nutrition component of SMI among many PHC workers. At immediate post- intervention and one month post-intervention (follow up), knowledge of experimental group increased while there was no significant change in the knowledge of nutrition component of SMI among the control group. It could be argued that the increase in knowledge among the experimental group was because the group was exposed to training intervention. This was in consonant with the study on the impact of training on the performance of Community Health Care Workers in New York City, which found that training improved the performance of this group of health workers on selected skills [10]. A study by Oshiname and Brieger, which adopted the quasi-experimental design, yielded this pattern of knowledge gain reported among the experimental and control groups at post-intervention [11]. It was observed that there was little improvement in the knowledge of the control at post-test, even though the group was not exposed to any training. 
The reason that could be provided for this observation can be linked with the fact that when the control group was asked some questions on nutrition component of SMI, they could not respond correctly. However, the questions asked might have prompted them to seek for answers to those questions before the post-testing. Although, this action did not provide them the leverage to answer the questions correctly like the trained group (the experimental) but it has influenced their knowledge to some extent and this could have been the reasons for showing poor knowledge at post-test rather than no knowledge shown at the pre-test in Tables 3 and 4 especially.

In this study, qualification, level of education, years of service and cadre/post of the experimental and control groups at preintervention, immediate post-intervention and one month post-intervention were not determinants of their knowledge of nutrition component of SMI and insignificantly different. This finding is in contradiction to Mehta and Helen who reported that educational qualification was a determinant of the level of knowledge regarding lead and lead poisoning among parents [12].

A comparison of the mean knowledge scores of the experimental and control groups at pre-intervention showed it was nil and insignificantly different. The comparison of the mean knowledge scores at immediate post-intervention and one month postintervention within the experimental and control groups indicated a significant difference only in the experimental group because they were exposed to training and this intervention increased their knowledge on the nutrition component of SMI. Similar results were obtained by Strange et al who conducted a study to assess the effects of a peer-led sex education training intervention on participant's knowledge and attitudes relating to sexual health issues and their perception of the impact of the peer education programme on them [13]. They observed a significant difference in the pre-test and post-test scores of the experimental group only. The knowledge of the intervention group increased at one month post-intervention because they all put into practice things they learnt at the training and the influence of text message as reinforcement may not be ruled out. Also, some of the participants might have engaged in self-study of the training manual that was given to them at the training over again.

\section{Impact evaluation of the training intervention}

The impact of the training intervention on the experimental group was measured one month after the training. Each of the participants explained how the knowledge acquired had helped them in giving nutrition information to the pregnant and lactating women who visited their clinics. They were able to counsel them to increase their intake of adequate nutrients essential during SMI, monitor their weight gain, counsel them to reduce energy expenditure/workload by using energy saving devices, diversify their diets, prescribe and provide iron and folic acid supplements for the pregnant ones. Also, recommend multiple micronutrient supplements, diagnose and treat those with severe anaemia, distribute vitamin A to post-partum women, discourage them from strenuous physical activity or work as the pregnancy advances, encourage women of reproductive age to observe more rest during pregnancy, advise to request family members to help with domestic chores, help to manage common symptoms related to food intake like vomiting, diarrhoea and loss of appetite.

\section{Participants perceived nutrition components of safe motherhood initiatives}

On comparing the perception of the experimental and control groups at baseline, immediate post- intervention and one month post-intervention relating to nutrition component of SMI, it was noted that all the participants had right perception. This observation did not corroborate what Dreyer found in an intervention aimed at assessing the effect of training on teachers' perception of violence against women in South Africa [14]. Dreyer noted that there was a change in perception after exposure to a training intervention.

\section{Conclusion and Recommendation}

The level of knowledge of health workers on nutrition component of SMI in both Egbeda and Ido LGAs at pre-intervention stage was nil. The training programme was found to be effective in improving the experimental group's knowledge on the nutrition component of SMI.

Lack of significant change in knowledge in the control group of health workers was a demonstration of the positive effects of the training intervention on the intervention group of health workers. A periodic in- service training on nutrition component of SMI is recommended to improve services rendered by PHC workers.

\section{Acknowledgement}

Support for this work was provided by Bill and Melinda Gates through the Centre for Population and Reproductive Health Office, College of Medicine, University of Ibadan, Nigeria.

\section{References}

1. Starrs AM (2006) Safe Motherhood Initiative: 20 years and counting. The Lancet 368: 1130-2.

2. Nigeria: Demographic and Health Survey (2009) National Population Commission, Federal Republic of Nigeria, Abuja, Nigeria in conjunction with ICF Macro Calverton, Maryland, USA. 
3. Pathfinder International (2004) POLICY Project and Islamic Scholars; Reproductive Health Issues in Nigeria: The Islamic Perspectives. Researched and Published by Renowned Islamic Scholars (ULAMA).

4. Safe Motherhood (2002).

5. Targeting Malnutrition (2009) Isotopic Tools for Evaluating Nutrition Worldwide.

6. Saving Newborn Lives in Nigeria (2011) Newborn Health in the context of the Integrated Maternal, Newborn and Child Health Strategy. Revised 2nd Edition, Abuja: Federal Ministry of Health, Save the Children, Jhpiego.

7. Brown JE, J Isaacs, B Krinke, M. Murtaugh and C Sharbaugh (2004) Nutrition through the Life Cycle, International Student Edition, Second Edition, USA.

8. Facts for Life (2010) Safe Motherhood.

9. Academy for Educational Development.

10. Perez M, Findley SE, Mejia M, Martinez J (2006) The impact of Community Health Workers training and programs in New York City. J Health Care Poor Underserved 17: 26-43

11. Oshiname FO, Brieger WR (1992) Primary care training for patent medicine vendors in rural Nigeria. Soc Sci Med 35: 1477-84.

12. Mehta S and JB Helen (1998) What do parents know about lead poisoning? The Chicago lead knowledge test. Arch Pediatr Adoles Med 152: 1213-8

13. Strange V, Forest S, Oakley A, the RIPPLE Study team (2002) Peer-led sex education characteristics of peer educators and perceptions of the impact of participation in a peer education programme. Health Edu Res 17: 327-37.

14. Dreyer A (2001) What Do We Want to Tell Our Children About Violence Against Women? A Project facilitated and managed by the School of Public Health, University of the Western Cape - in association with The POLICY Project and The Rural AIDS \& Development Action Research Program (RADAR).

15. Maine D, Rosenfield A (1999) The Safe Motherhood Initiative: why has it stalled? Ame J Public Health 89: 480-2.

16. Ladipo OA (2000) Nutrition in pregnancy: mineral and vitamin supplements. Am J Clin Nutr July 72: 280-290S.

17. Tinker A, Ransom E (2002) Healthy Mothers and Healthy Newborns: The Vital Link. Policy Perspectives on Newborn Health.

18. Mora JO, Nestel PS (2000) Improving prenatal nutrition in developing countries: strategies, prospects, and challenges. Am J Clin Nutr 71: 1353-63S.

19. Rush D (2000) Nutrition and maternal mortality in the developing world. Am J Clin Nutr 72: 212-40S.

20. Koblinsky MA, Campbell O, Heichelheim J (1999) Organizing delivery care: what works for safe motherhood? Bull World Health Organ 77: $399-406$.

21. Essential Nutrition Actions Framework (2011) Booklet on Key ENA Messages. USAID.

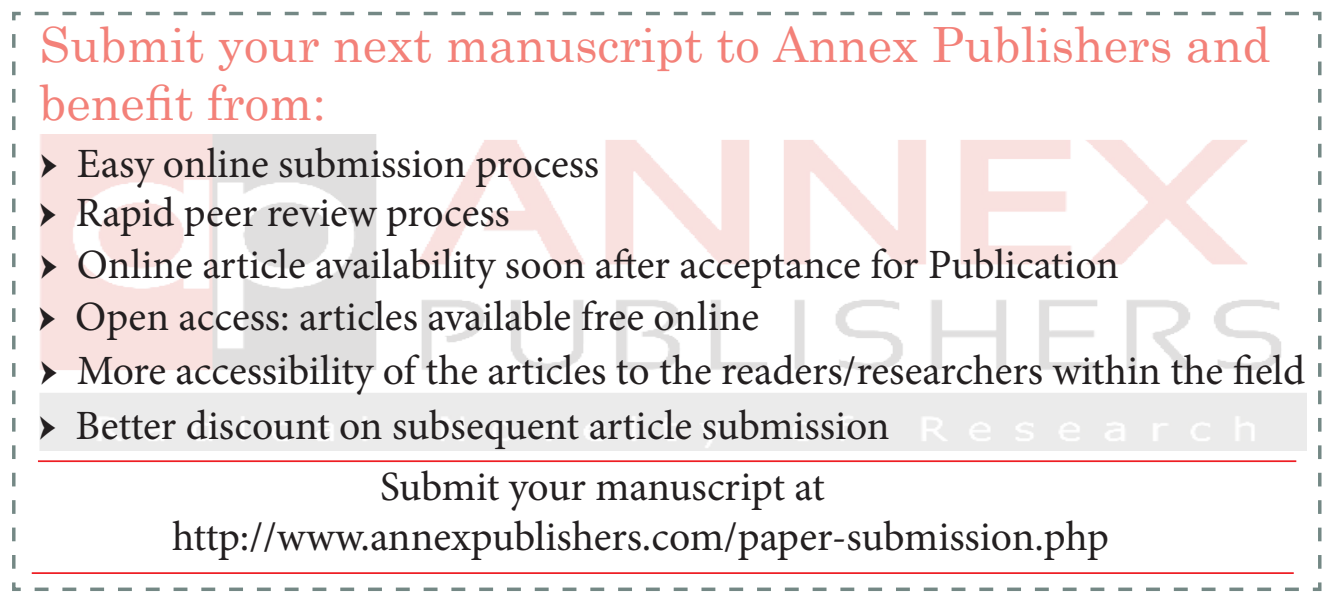

